\title{
METABOLIC SYNDROME AND NONALCOHOLIC FATTY LIVER DISEASE
}

\author{
Oana Irina Gavril, Lidia Iuliana Arhire, Ovidiu Mitu, Radu Sebastian Gavril, \\ Alexandra Mastaleru, Madalina Ioana Zota, Maria-Magdalena Leon-Constantin, \\ Teodor Vasilcu, Laura Mihalache, Florin Mitu \\ "Grigore T.Popa" University of Medicine and Pharmacy Iasi, Romania \\ Corresponding author: \\ Radu Sebastian Gavril \\ University of Medicine and Pharmacy Iasi, Str Universitatii 16 \\ e-mail: rgavril87@yahoo.com
}

\begin{abstract}
Introduction. Non-alcoholic fatty liver disease (NAFLD) is regarded as the hepatic expression of the metabolic syndrome, both conditions presenting similar clinical features.
\end{abstract}

Aim. The aim of this study was to evaluate, among diabetic subjects, the relationship between fatty liver load and the presence of metabolic syndrome criteria.

Methods. An observational study was conducted on 92 subjects with type 2 diabetes. We followed anthropometric measurments, lipid profile, blood pressure and the degree of hepatic steatosis using ultrasonography.

Results. The average age of the study group was 60,38 $\pm 10,37$ years, with an approximately equal distribution by gender (48\% male and 52\% female). More than half of the subjects presented hypercholesterolemia, hypertriglyceridemia, and low HDL cholesterol level. Most of the patients included in the study had varying degrees of liver fat load (only 9,89\% of cases of apparently normal liver on ultrasound), and met the criteria for metabolic syndrome (81,31\%). It was found that the frequency of the cases with fatty liver impairment was significantly higher in subjects with metabolic syndrome $(32,43 \%$ compared to 5,88\% for those without metabolic syndrome, $p=0,01$ ) and the frequency of the cases with normal liver were significantly higher in subjects without metabolic syndrome $(23,53 \%$ to $6,76 \%, p=0,02)$.

Conclusion. We can say that NAFLD is a risk factor for the presence of metabolic syndrome and it can be considered the hepatic expression of this syndrome.

Key words: fatty liver disease, metabolic syndrome, lipid, cardiovascular risk. 


\section{Ceneral Reverus}

\section{Rezumat}

Introducere. Ficatul gras nonalcoolic (NAFLD) este considerat expresia hepatică a sindromului metabolic, întrucât cele două afecțiuni împart manifestări clinice similare.

Scop. Scopul acestui studiu a fost de a evidenția, în rândul populației diabetice, relația dintre gradul de încărcare grasă hepatică și prezența criteriilor de sindrom metabolic.

Material și metodă. A fost realizat un studiu observațional pe un număr de 92 subiecți cu diabet zaharat de tip 2. S-au urmărit indicii antropometrici, profilul lipidic, tensiunea arterială și încărcarea grasă hepatică, utilizând ultrasonografia abdominală.

Rezultate. Vârsta medie a lotului studiat a fost de 60,38 \pm 10,37 ani, cu o repartiție aproximativ egală în funcție de sex (48\% bărbați și 52\% femei). Mai mult de jumătate dintre subiecți au prezentat hipercolesterolemie, hipertrigliceridemie și hipoHDL colesterolemie. Marea majoritate a pacienților incluși în studiu au prezentat diferite grade de încărcare grasă hepatică (doar 9,89\% cazuri de ficat cu aspect normal ecografic) și au întrunit criteriile de sindrom metabolic (81,31\%). S-a constatat că frecvența cazurilor cu steatoză hepatică severă a fost semnificativ mai mare la subiecții cu sindrom metabolic $(32,43 \%$ față de 5,88\% la cei fără sindrom metabolic, $p=0,01$ ), iar frecvența cazurilor cu ficat normal a fost semnificativ mai mare la subiecții fără sindrom metabolic $(23,53 \%$ față de $6,76 \%, p=0,02)$.

Concluzii. Putem afirma faptul că NAFLD reprezintă un factor de risc pentru prezența sindromului metabolic și poate fi considerată expresia hepatică a acestui sindrom.

Cuvinte cheie: ficat gras, sindrom metabolic, lipide, risc cardiovascular. 


\section{INTRODUCTION}

Nonalcoholic fatty liver disease (NAFLD) is the most common hepatic affection and it is strongly associated with cardiovascular disease. NAFLD is considered the hepatic expression of the metabolic syndrome (MS), sharing similar clinical manifestations ${ }^{(1)}$. The prevalence of this hepatic pathology is higher in subjects with type 2 diabetes mellitus (DM2).

It is said that NAFLD precedes the development of DM2 and metabolic syndrome ${ }^{(2)}$, increasing the risk of developing DM2, even in subjects with a normal body mass index $(\mathrm{BMI})^{(3)}$.

The first diagnostic criteria were described in $1999^{(4)}$, when NAFLD was divided into four subtypes: type 1 - only fatty liver loading, type 2 - liver fat load plus lobular inflammation, type 3 - ballooning of the hepatocyte and cell degeneration and type 4 - cell ballooning and Mallory - Denk bodies of fibrosis.

Histological feature of NAFLD is the hepatic accumulation of fat (triglycerides), without secondary causes of hepatic steatosis alcohol consumption, steatogenic drugs or hereditary diseases ${ }^{(5)}$. The normal triglycerides content in human liver tissue is $5,5 \%$ of its weight ${ }^{(6,7)}$. Histologically, liver steatosis is considered when $>5 \%$ of the hepatocytes present macrovesicular fatty degeneration ${ }^{(8,9,10)}$.

The relationship between obesity and hepatic steatosis is wellknown. The global burden of obesity is associated with a high prevalence of metabolic syndrome and NAFLD. NHANES survey results showed that both obesity and NAFLD are incresing ${ }^{(11)}$.

The strong link between metabolic syndrome and NAFLD is based both on the pathophysiological and epidemiological point of view. Regarding pathophysiology, NAFLD is associated with insulinresistance and hepatic insulin inability in stopping hepatic glucose production ${ }^{(12)}$. This leads to mild hyperglycemia and stimulation of insulin secretion, resulting in hyperinsulinemia. Normally insulin inhibits the hepatic production of very low density lipoprotein cholesterol (VLDLC). The overproduction of VLDLC and the inability of insulin to inhibit this process is correlated with the hepatic fatty loading ${ }^{(13)}$.

Liver fat content is associated with the components of the metabolic syndrome, independent of the BMI. Furthermore, hepatic steatosis is reported to be four times more frequent among pacients with metabolic syndrome compared to control subjects $^{(14)}$. Thus, metabolic syndrome is universally recognised as the main risk factor for NAFLD and it is suggested that fatty liver might be included as a criteria for metabolic syndrome ${ }^{(15)}$.

\section{AIMS AND OBJECTIVES}

The aim of the study was to determine the prevalence of NAFLD among DM2 subjects and to evaluate the link between the severity of hepatic steatosis and the presence of metabolic syndrome criteria.

\section{MATERIALS AND METHODS}

An observational study was conducted on 92 DM2 subjects. They were evaluated regarding fatty liver loading using abdominal ultrasonography, anthropometric indices, lipid profile and blood pressure measurment. The inclusion criteria for the study were DM2 treated with oral drugs and/or diet and the exclusion criteria were represented by insulin therapy, viral hepatic infection $(B, C)$, 


\section{INTERNAL}

\section{General Reviews}

toxic hepatopathy, other liver diseases.

The level of hepatic steatosis was assessed using a portable ultrasound Carewell 12 with convex probe of $3,5 \mathrm{MHz}$. All the subjects were evaluated by the same investigator. The abdominal ultrasonographies were taken after fasting for at least 8 hours, in order to avoid abdominal bloating .

The patients were evaluated regarding the components of the metabolic syndrome, using IDF criteria(16):

- Waist circumference (WC) - normal values $<80 \mathrm{~cm}$ in women and $<94 \mathrm{~cm}$ in men.

- Hypertension - previous diagnosis of hypertension or higher values than $130 \mathrm{mmHg}$ for the systolic blood pressure or $85 \mathrm{mmHg}$ for the diastolic blood pressure at the time of the clinical examination.

- Hypertriglyceridemia (>150 mg/dl).

- Low values for high density lipoprotein cholesterol (HDLC) $(<40 \mathrm{mg} / \mathrm{dl}$ in men, $<50 \mathrm{mg} / \mathrm{dl}$ in women).

- Hyperglycemia or DM2 (this criteria was met for all the included subjects)

The criteria for metabolic syndrome were met in the presence of three of the five conditions (abdominal obesity - mandatory) (16).

The database was created in Microsoft Excel, without including ID data of the subjects. The statistical analysis was made in Statistica, version 7.0. We considered $p<0.05$ as statistically significant.

\section{RESULTS}

The group of 92 subjects was represented by 44 men (47.83\%) and 48 women (52.17\%). According to the provenance environment, 68 subjects belonged to the urban environment $(73.91 \%)$ and 24 to the rural environment (26.09\%). The average age was of $60.38 \pm 10.37$ years, varying between the ages of 33 and 86 . More than $90 \%$ of the subjects presented different degrees of hepatic steatosis (Figure 1).

We noticed no statistically significant correlations according to sex regarding the incidence of normal liver and hepatic steatosis cases. $75 \%$ of the subjects presented high blood pressure values. More than half of the study group presented hypercholesterolemia, hypertrigliceridemia and hipo HDL cholesterolemia.

The frequency of normal liver and mild steatosis cases was significantly higher in subjects with normal values of HDLc, while moderate and severe steatosis were associated with low values of HDLc. Moderate and severe steatosis was also associated with abnormal levels of triglycerides.

The vast majority of the subjects $(81,31 \%)$ met the criteria for metabolic syndrome. 


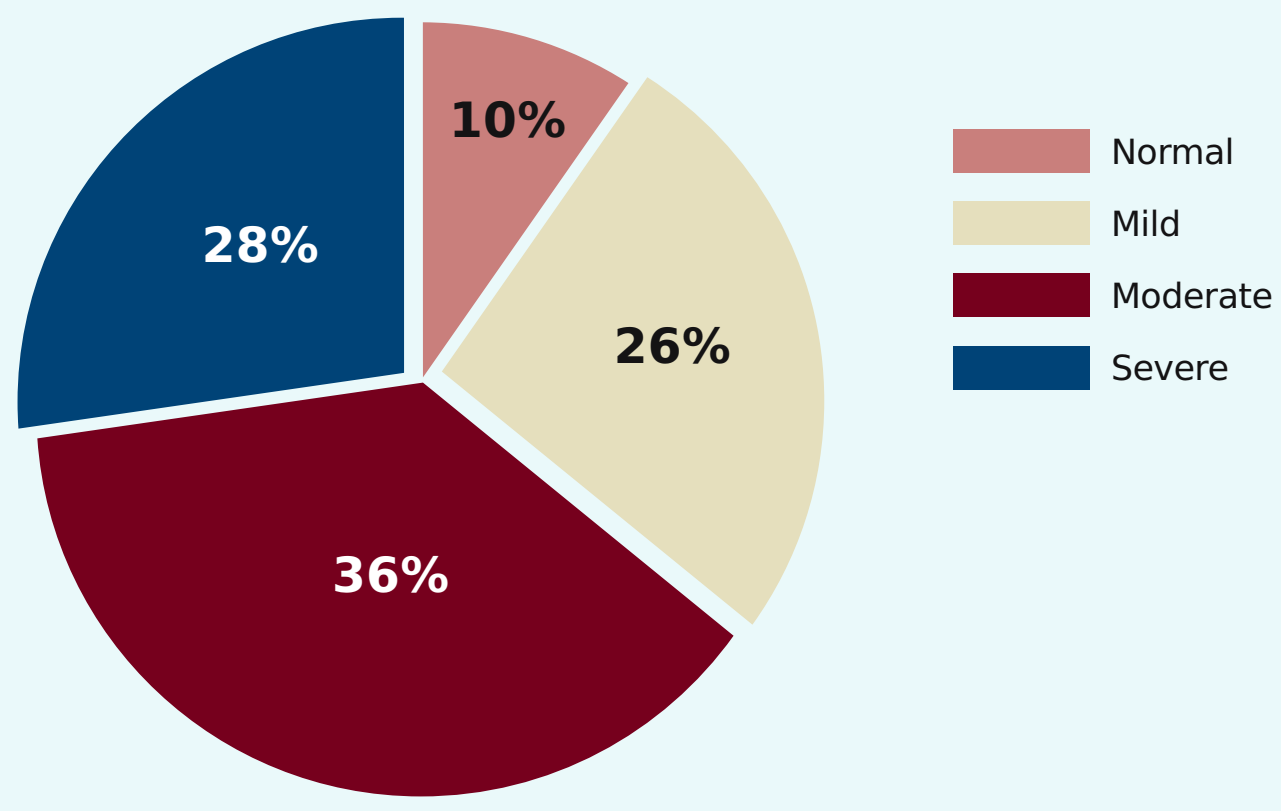

Figure 1. Degrees of hepatic steatosi

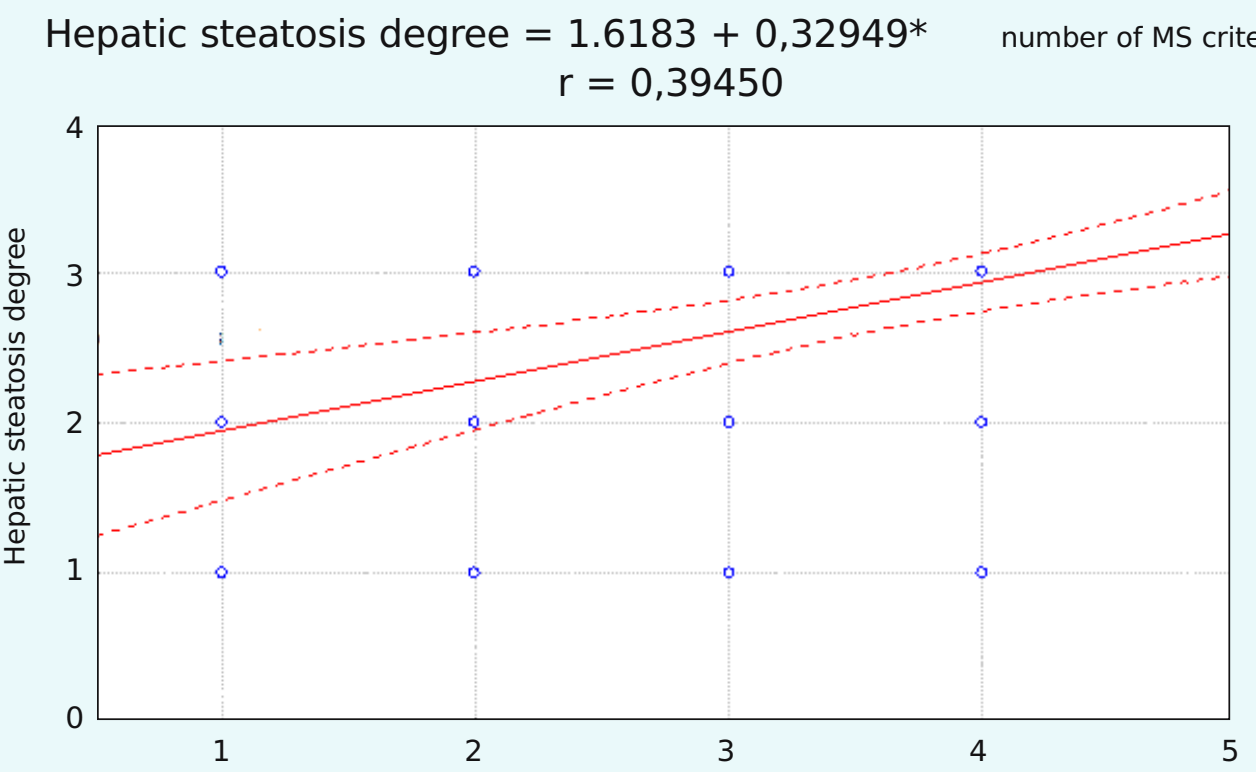

Figure 2. Degree of hepatic steatosis and the number of metabolic syndrome criteria 


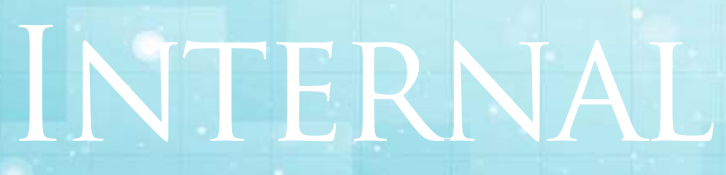

\section{General Reviews}

The frequency of severe steatosis cases was significantly higher in subjects with metabolic syndrome $(32,43 \%$ compared to $5,88 \%, p=0,01$ ) and the normal liver cases were associated with subjects without metabolic syndrome $(23,53 \%$ to $6,76 \%$, $\mathrm{p}=0,02$ ).

In addition to these findings, there was a statistically significant relationship between fatty liver loading and the number of metabolic syndrome criteria (Figure 2 ).

\section{DISCUSSION AND CONCLUSION}

The prevalence of hepatic steatosis in the studied group was more than $90 \%$, data which is also shown in other studies, where the prevalence of this hepatic condition is mentioned between 70 and 90\% among patients with $\mathrm{DM} 2^{(17,18)}$. The prevalence is even higher in obese subjects ${ }^{(19)}$. The high prevalence of steatosis obtained in our research might be explained by the particular eating habits in our country (high saturated fats diet) combined with a sedentary lifestyle. As regards the studied group, we noticed no statistically significant correlations according to sex regarding the incidence of normal liver and hepatic steatosis cases, although other researchers claim that males present a higher risk for hepatic steatosis ${ }^{(20)}$.

Visceral fat seems to be closely correlated with liver fatty load ${ }^{(14)}$. This explains to some extent the association between metabolic syndrome and NAFLD. In addition to this, the independent relationship between central obesity and increased morbidity and mortality is well established(21). Hyperlipidemia, especially due to hypertriglyceridemia is a primary risk factor for NAFLD and it even represents a consequence of NAFLD ${ }^{(22)}$. In our study, serum triglyceride level was significantly correlated with the degree of hepatic steatosis.

DM2 is a major health problem, affecting nearly 350 million people. Diabetes and NAFLD are particularly closely related $^{(23,24)}$. Prevalence of NAFLD was proved to be higher in patients with DM2 and these subjects have a high risk of developing nonalcoholic steatohepatitis (NASH) ${ }^{(25)}$. The National Health and Nutrition Examination Survey (NHANES) showed that DM2 is an independent predictor for NAFLD (26). There is evidence that the reverse relationship is also true: in subjects without DM2, NAFLD might be a predictor for the incidence of diabetes ${ }^{(27)}$.

A japanese study showed that subjects with metabolic syndrome are prone to develop NAFLD ${ }^{(28)}$. The association between NAFLD and metabolic syndrome might be the consequence of insulinresistance. Our study shows that the frequency of severe steatosis 
cases were significantly higher in subjects with metabolic syndrome. Abdominal obesity and metabolic syndrome lead to hepatic steatosis, both by improving the transport of fatty acids by the liver and by increasing hepatic lipogenesis which is associated with hyperinsulinemia ${ }^{(29)}$. At the same time, the associated insulinresistence may also worsen metabolic syndrome.

The close link between fatty liver, obesity and cardiometabolic risk factors lead to the idea that hepatic steatosis may be a new component of the metabolic syndrome ${ }^{(30)}$. We conclude that NAFLD is a risk factor regarding cardiovascular disease and it can be seen as the hepatic manifestation of the metabolic syndrome.

\section{Bibliography}

1. Yki-Jarvinen. H. Non-alcoholic fatty liver disease as a cause and a consequence of metabolic syndrome. Lancet Diabetes Endocrinol 2014; 2(11): 901-10

2. Lonardo A, Ballestri S, Marchesini $G$ et al. Nonalcoholic fatty liver disease: $A$ precursor of the metabolic syndrome. Dig Liver Dis 2015; 47: 181-90.

3. Fukuda T, Hamaguchi M, Kojima $T$ et al. The impact of non-alcoholic fatty liver disease on incident type 2 diabetes mellitus in non-overweight individuals. Liver Int 2016; 36: 275-83.

4. Matteoni C, Younossi Z, Gramlich T et al. Nonalcoholic fatty liver disease: $\underline{A}$ spectrum of clinical and pathological severity. Gastroenterology 1999; 116: 1413-19.

5. Chalasani N, Younossi Z, Lavine JE et al. The diagnosis and management of nonalcoholic fatty liver disease: practice Guideline by the American Association for the Study of Liver Diseases, American College of Gastroenterology, and the American Gastroenterological Association. Hepatology 2012; 55: 2005-23.

6. Donhoffer H. Quantitative estimation of lipids in needle biopsy sized specimens of cadaver liver. Acta Med Acad Sci Hung 1974; 31: 47-49.

7. Hoyumpa AM Jr, Greene HL, Dunn GD, Schenker S. Fatty liver: Biochemical and clinical considerations. Dig Dis Sci 1975; 20: 1142-70.

8. Korenblat KM, Fabbrini E, Mohammed BS, Klein S. Liver, muscle, and adipose tissue insulin action is directly related to intrahepatic triglyceride content in obese subjects. Gastroenterology 2008; 134: 1369-75.
9. Brunt EM, Tiniakos DG. Histopathology of nonalcoholic fatty liver disease. World J. Gastroenterol 2010; 16: 5286-96.

10. Bedossa P, Poitou C, Veyrie $N$ et al. Histopathological algorithm and scoring system for evaluation of liver lesions in morbidly obese patients. Hepatology 2012; 56: 1751-9.

11. Flegal KM, Carroll MD, Kit BK et al. Prevalence of obesity and trends in the distribution of body mass index among US adults, 1999-2010. JAMA 2012; 307(5): 491-7. 12. Bugianesi E, Moscatiello S, Ciaravella MF, Marchesini G. Insulin resistance in nonalcoholic fatty liver disease. CurrPharm Des 2010; 16: 1941-51.

13. Gaggini M, Morelli M, Buzzigoli E et al. Non-alcoholic fatty liver disease (NAFLD and its connection with insulin resistance, dyslipidemia, atherosclerosis and coronary heart disease. Nutrients 2013; 5: 1544-60.

14. Kotronen A, Westerbacka J, Bergholm R et al. Liver fat in the metabolic syndrome. J Clin Endocrinol Metab 2007; 92: 3490-7.

15. Uchil D, Pipalia D, Chawla M et al. Non-alcoholic fatty liver disease (NAFLD) - the hepatic component of metabolic syndrome. J Assoc Physicians India 2009; 57: 201-4.

16. Alberti KG, Eckel RH, Grundy SM, et al. Harmonizing the metabolic syndrome: a joint interim statement of the International Diabetes Federation Task Force on Epidemiology and Prevention; National Heart, Lung, and Blood Institute; American Heart Association; World Heart Federation; International Atherosclerosis Society; and International Association for the Study of Obesity. Circulation. 2009; 120: 1640-5

17. Williamson RM, Price JF, Glancy $S$ et al. Edinburgh Type 2 Diabetes Study Investigators. Prevalence of and risk factors for hepatic steatosis and nonalcoholic fatty liver disease in people with type 2 diabetes: The Edinburgh Type 2 Diabetes Study. Diabetes Care 2011; 34: 1139-44.

18. Dai W. : Prevalence of nonalcoholic fatty liver disease in patients with type 2 diabetes mellitus: $A$ metaanalysis, Medicine (Baltimore) 2017; 96(39)

19. Bellentani, S.; Tiribelli, C.: Epidemiology and risk factors for fatty liver. In: Leuschner $U$, James OFW, Dancyguer $H$ (eds.). Steatohepatitis (NASH and ASH), Kluwer Academic Publishers: Dordrecht 2001; 3-10

20. Vernon G, Baranova A, Younossi ZM. Systematic review: the epidemiology and natural history of nonalcoholic fatty liver disease and non-alcoholic steatohepatitis in adults. Aliment Pharmacol Ther 2011; 34(3): 274-85

21. Donahue RP, Abbott RD, Bloom E et al. Central obesity and coronary heart disease in men. Lancet 1987; 1: 821-4. 


\section{I}

General Reviews

22. Baldridge AD, Perez-Atayde AR, Graeme-Cook Fet al. Idiopathic steatohepatitis in

childhood: a multicenter retrospective study. J Pediatr 1995, 127: 700-4.

23. Firneisz G. Non-alcoholic fatty liver disease and type 2 diabetes mellitus: the liver disease of our age? World J Gastroenterol 2014; 20: 9072-89.

24. Leite NC, Villela-Nogueira CA, Cardoso CR et al. Nonalcoholic fatty liver disease and diabetes: from physiopathological interplay to diagnosis and treatment. World J Gastroenterol 2014; 20: 8377-92.

25. Leite NC, Villela-Nogueira CA, Pannain VL el al. Histopathological stages of nonalcoholic fatty liver disease in type 2 diabetes: prevalences and correlated factors. Liver Int 2011; 31: 700-6.
26. Younossi Z, Page S, Rafiq $N$ et al. A biomarker panel for nonalcoholic steatohepatitis (NASH) and NASHrelated fibrosis. Obes Surg 2011; 21: 431-9.

27. Verderese $J P$, Younossi Z. Interaction of type 2 diabetes and nonalcoholic fatty liver disease. Expert Rev Gastroenterol Hepatol 2013; 7: 405-7.

28. Hamaguchi M, Kojima T, Tekeda $N$ et al. The metabolic syndrome as a predictor of nonalcoholic fatty liver disease. Ann Intern Med 2005; 143: 722-8.

29. Browning JD, Horton JD. Molecular mediators of hepatic steatosis and liver injury. J Clin Invest 2004; 114: 147-52.

30. Kotronen A, Yki-Jarvinen H. Fatty liver. A novel component of the metabolic syndrome. Arterioscler Thromb Vasc Biol 2008; 28: 27-38. 